\title{
Gambaran Pelaksanaan Kegiatan Pembelajaran untuk Meningkatkan Kemampuan Literasi Matematika Siswa
}

\author{
Overview of Implementation of Learning Activities to Improve Students' Math Literacy \\ Ability
}

Rahma Muti'ah"
Irmayanti
Department of Mathematics
Education, Universitas Labuhanbatu,
Labuhan Batu, North Sumatera,
Indonesia
'email: rmuthea5@gmail.com
Kata Kunci
Literasi Matematika
Pendekatan Matematika Realistik
Minat Baca
Token Ekonomi
Keywords:
Mathematical Literacy
Realistic Mathematical Approach
Interest in Reading
Economic Token
Received: October 2019
Accepted: January 2020
Published: March 2020

\begin{abstract}
Abstrak
Salah satu indikator yang dapat dijadikan keberhasilan proses pendidikan adalah nilai kemampuan literasi matematika siswa. Di SMP Negeri 3 Satu Atap Aek Natas dari 122 sampel diperoleh hasil 87 siswa masih tergolong rendah. Kemampuan literasi matematika dipengaruhi antara lain minat membaca matematika dan dukungan sosial keluarga yang rendah. Untuk itu solusi yang ditawarkan dalam pelaksanaan pengabdian adalah dengan melakukan kegiatan pembelajaran dengan pendekatan PMR berbantuan resitasi, penerapan prinsip token ekonomi disertai dengan penggunaan buku penghubung. Peserta dalam pelaksanaan pengabdian ini terdiri dari 30 siswa, 30 orangtua/wali siswa, dan 15 orang guru. Berdasarkan dari hasil pelaksanaan pengabdian diperoleh ada peningkatan nilai rerata kemampuan literasi, minat membaca dan dukungan sosial keluarga sebelum pelaksanaan dengan sesudah pelaksanaan pengabdian.
\end{abstract}

\begin{abstract}
One indicator that can be used as a success in the educational process is the value of students' mathematical literacy abilities. In Satu Atap Aek Natas Junior Secondary School out of 122 samples, the results of 87 students are still relatively low. Mathematical literacy is influenced by, among others, the interest in reading mathematics and low family social support. For this reason, the solution offered in the implementation of community service is to carry out learning activities using a recitationassisted PMR approach, the application of the principle of economic tokens accompanied by the use of a contact book. Participants in the implementation of this service consisted of 30 students, 30 parents/guardians of students, and 15 teachers. Based on the results of the implementation of community service there is an increase in the average value of literacy skills, interest in reading and social support of the family before the implementation and after the implementation of service.
\end{abstract} Muhammadiyah Palangkaraya. This is Open Access article under the CC-BY-SA License (http://creativecommons.org/licenses/by-sa/4.0/). DOI: https:// doi.org/10.33084/pengabdianmu.v5i2.992.

\section{PENDAHULUAN}

Tujuan dari proses pendidikan di sekolah adalah mutu lulusan yang berhubungan langsung dengan mutu sekolah tersebut. Tinggi atau rendahnya mutu dari sebuah kegiatan pendidikan disekolah salah satunya dapat dilihat dari tinggi atau rendahnya skor PISA yang diperoleh siswa. Dari hasil laporan PISA pada tahun 2015 disebutkan bahwa peringkat Indonesia adalah 64 dari 65 negara dengan skor 386 dari skor yang terendah adalah 375. Dari skor ini menjadi bukti bahwa kemampuan matematika siswa Indonesia umumnya masih sangat rendah (Masjaya \& Wardono, 2018). Untuk meningkatkan skor PISA tersebut salah satunya adalah dengan meningkatkan kemampuan literasi matematika. Seorang siswa yang memiliki kemampuan literasi matematika, maka siswa tersebut akan memiliki kemampuan untuk dapat membuat sebuah perkiraan, 
menginterpretasikan data, menyelesaikan permasalahan-permasalahan yang dihadapi sehari-hari, dapat menunjukkan kesimpulan dari suatu permasalahan dalam bentuk grafik dan geometri dan dapat mengkomunikasikan matematika (Madyaratria et al., 2019).

Rendahnya kemampuan literasi matematika juga terjadi di SMP Negeri 3 Satu Atap, sekolah ini merupakan sebuah sekolah negeri yang berlokasi di Desa Simonis Kec. Aek Natas Kabupaten Labuhanbatu Utara. Sebagai SMP Negeri Satu Atap, masih memiliki banyak permasalahan dalam peningkatan mutu sekolah. Berdasarkan pada hasil penelitian pendahuluan di sekolah tersebut berkaitan dengan program Gerakan Literasi Nasional yang diprogram kan oleh Pemerintah, diperoleh hasil skor PISA siswa rendah, dari 122 siswa kelas VII hingga kelas IX diperoleh hasil; 1) siswa yang berada pada kategori tinggi 12 siswa, 2) siswa yang berada pada kategori sedang 23 siswa, 3) dan siswa yang berada pada kategori rendah ada 87 siswa. Dari hasil ini terlihat bahwa kemampuan literasi matematika siswa di SMP Negeri 3 Satu Atap tergolong rendah.

Banyak faktor yang mempengaruhi rendahnya kemampuan literasi matematika siswa. Diantaranya adalah minat membaca terutama buku matematika dan dukungan sosial keluarga dalam hal meningkatkan kebiasaan membaca (Kharizmi, 2015). Pada penelitian pendahuluan peneliti juga mengukur minat membaca buku matematika siswa dan dukungan sosial keluarga siswa. Dari hasil penelitian diperoleh bahwa dari 122 siswa yang dijadikan subjek penelitian diperoleh; 1) siswa dalam kategori tinggi minat membaca dan dukungan sosial keluarga berturut-turut adalah 20 siswa dan 30 siswa, 2) siswa yang berada pada kategori sedang untuk minat membaca matematika dan dukungan sosial keluarga berturut-turut adalah 40 siswa dan 40 siswa, sedangkan 3) siswa yang memiliki kategori rendah dalam hal minat membaca buku matematika dan dukungan sosial keluarga berturut-turut adalah 62 siswa dan 55 siswa (Muti'ah, 2017).

Berdasarkan hasil penelitian awal tersebut terlihat dimungkinkan ada pengaruh minat membaca buku matematika dan dukungan sosial keluarga terhadap kemampuan literasi matematika siswa. Hal ini didukung penelitian yang telah dilakukan oleh Kaisar (2017) bahwa ada hubungan antara minat baca dengan kemampuan literasi matematika. Hal ini juga di dukung dari hasil penelitian pendahuluan yang dilakukan pengusul yang menemukan minat membaca matematika rendah. Padahal minat membaca menjadi salah satu faktor yang mempengaruhi kemampuan literasi matematika, siswa yang memiliki minat membaca matematika rendah maka kemampuan literasi matematikanya juga rendah (Mahdiansyah \& Rahmawati, 2014).

Selain minat membaca yang dapat mempengaruhi kemampuan literasi matematika adalah dukungan sosial baik dari teman, keluarga, guru dan pihak sekolah. Dukungan disini maknanya membantu siswa untuk memiliki kebiasaan belajar yang baik dan memastikan siswa mengerjakan tugas-tugas, mengingatkan siswa untuk mengulang materi pembelajaran di rumah (Cahyani, 2016). Untuk itu, berdasarkan dari hasil penelitian pendahuluan tersebut, hal yang dilakuan dalam pelaksanaan pengabdian ini sebagai upaya meningkatkan kemampuan literasi matematika siswa adalah dengan dua cara yaitu meningkatkan minat membaca matematika siswa melalui teknik modifikasi perilaku berupa token ekonomi, buku latihan soal, self control, dan buku penghubung dan dengan menerapkan metode pembelajaran dengan pendekatan PMR (Pendekatan Matematika Realistik) yang mana tujuan pembelajaran disesuikan dengan indikator kompetensi literasi matematika. 
Alasan penggunaan modifikasi perilaku untuk meningkatkan minat membaca siswa dikarenakan minat membaca adalah rasa ketertarikan siswa terhadap bahan bacaan matematika yang ditunjukkan dengan perilaku membaca bahan/literatur matematika (Arisma, 2012). Selain itu minat membaca matematika adalah salah satu faktor yang mempengaruhi kemampuan literasi matematika siswa, siswa yang tidak memiliki minat membaca matematika akan kesulitan untuk memiliki kompetensi literasi matematika. Diharapkan jika minat membaca matematika siswa tinggi maka siswa dapat dilatih untuk meningkatkan kompetensi literasi matematika dirinya (Siswowijoyo \& Tiya, 2014). Modifikasi perilaku yang dilakukan dengan dibantu teknik token ekonomi, buku latihan soal, self control, buku penghubung antara orangtua dan guru. Dengan asumsi bahwa jika siswa mendapatkan hadiah dalam bentuk token ekonomi ketika dia berhasil membaca bahan matematika, menyelesaikan soal-soal matematika pada buku latihan soal, selain itu juga siswa memiliki buku Self control yang tujuannya sebagai pembelajaran bagi siswa untuk membaca dan mengerjakan soal, sedangkan buku penghubung orangtua dan guru adalah pengontrol hasil kegiatan membaca siswa dirumah dan diperiksa oleh guru. Sehingga guru dan orangtua memberikan dukungan sosial untuk meningkatkan kemampuan literasi matematika siswa (Rahmani et al., 2017).

Selain dengan teknik modifikasi perilaku juga dilakukan dengan pembelajaran dengan pendekatan matematika realistik. Dengan asumsi jika pembelajaran dilakukan dengan pendekatan matematika realistik maka siswa belajar dengan konsep realistik yang mana kompetensi literasi matematika juga berkaitan dengan kompetensi siswa untuk menyelesaikan permasalahanpermasalahan yang "real".

\section{METODOLOGI}

Alat atau bahan yang digunakan dalam pelaksanaan pengabdian adalah sebagai berikut:

\section{Modul PMR}

Modul PMR adalah buku panduan yang dimiliki oleh tim pelaksana untuk melaksanakan kegiatan pembelajaran PMR dalam upaya meningkatkan kemampuan literasi matematika siswa. Modul berisi tentang langkah-langkah pembelajaran yang akan dilakukan pada setiap pertemuan, dari pertemuan pertama hingga pertemuan ke 24 .

2. Daftar aturan pemberian token dan penukaran hadiah

Daftar ini berisi tentang syarat dan ketentuan untuk mendapatkan atau kehilangan token. Di dalam daftar aturan ini juga terdapat daftar-daftar hadiah yang dapat ditukarkan siswa dengan token-token yang sudah dikoleksi oleh siswa.

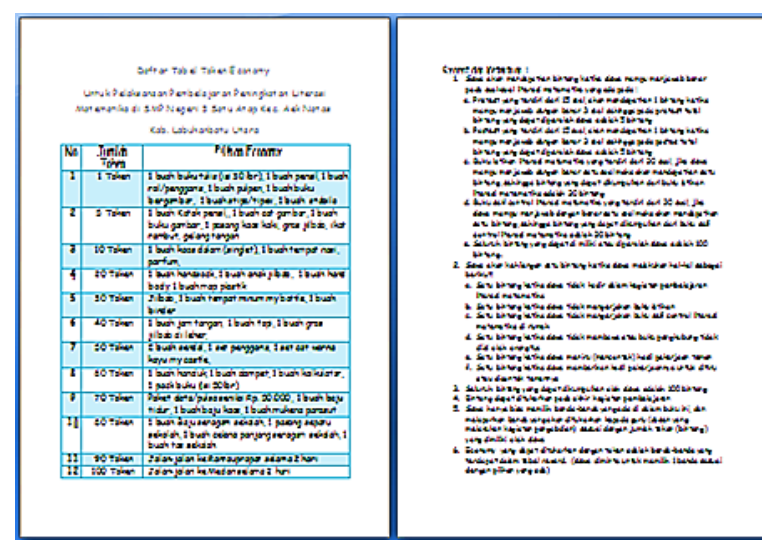

Gambar 1. Buku token

3. Buku pretes

Buku Soal Pretes tentang kemampuan literasi matematika, Angket minat membaca dan angket dukungan sosial Keluarga. 


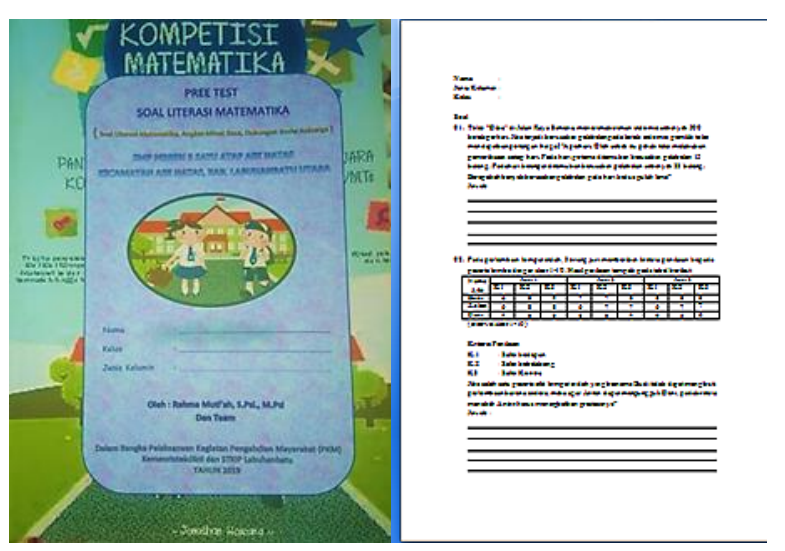

Gambar 2. Buku pretes

4. Buku postes

Buku Soal Postes tentang kemampuan literasi matematika, Angket minat membaca dan angket dukungan sosial keluarga.
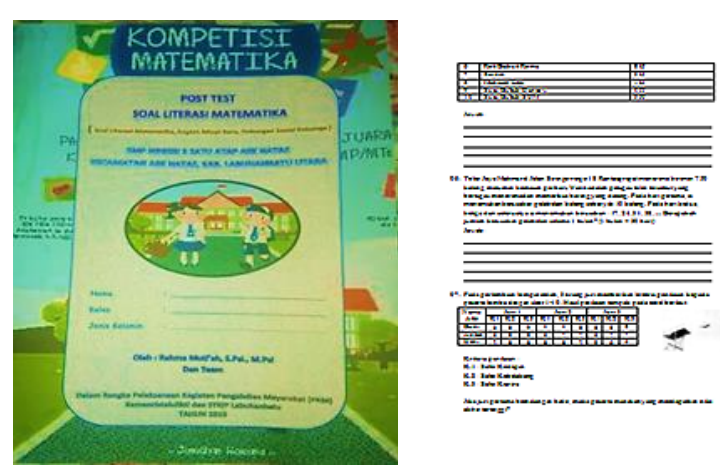

Gambar 3. Buku postes

5. Buku latihan soal

Buku latihan soal adalah buku yang digunakan siswa untuk melatih kemampuan literasi matematika siswa sebelum siswa mendapatkan materi pembelajaran. Ketika siswa mampu menyelesaikan tugas dengan benar maka siswa berhak untuk mendapatkan token "star" dan ditempel di kolom yang sudah disediakan. Adapun tampilan dari buku latihan soal adalah sebagai berikut:

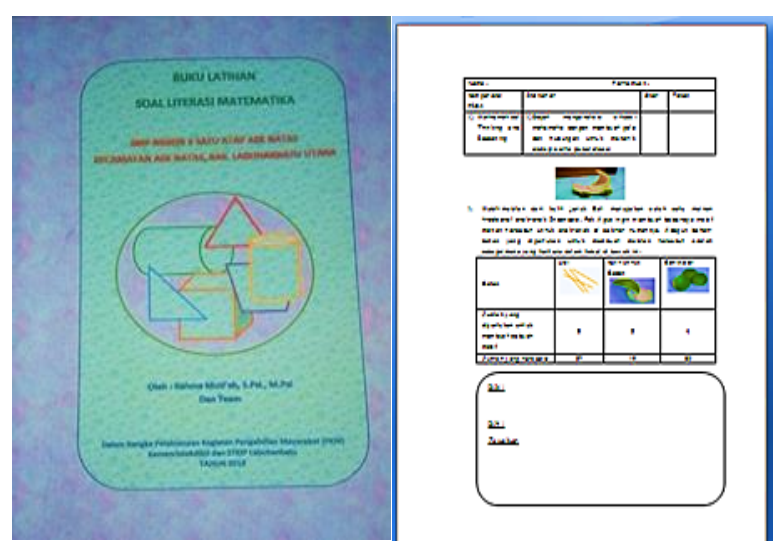

Gambar 4. Buku latihan soal

6. Buku "self control"

Buku "self control" adalah buku yang digunakan siswa untuk membantu siswa belajar di rumah, buku ini juga dijadikan buku pengukur kemampuan siswa setelah mendapatkan materi pembelajaran di kelas. Siswa setiap hari akan diberikan tugas yang terdapat di dalam buku "selfcontrol" untuk mereka kerjakan di rumah. Ketika siswa mampu menjawab dengan benar maka akan berhak untuk mendapatkan satu token dan ditempelkan di kolom yang telah disediakan. Adapun tampilan buku "self control" adalah sebagai berikut:

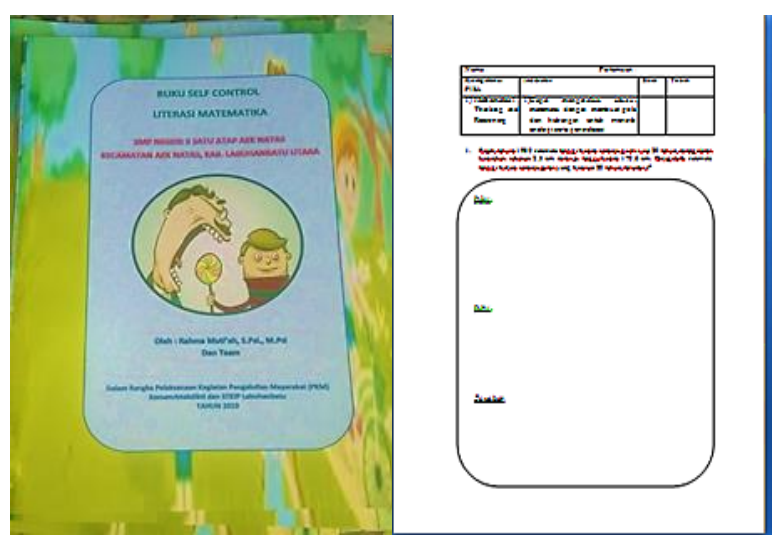

Gambar 5. Buku self control

\section{Buku penghubung}

Buku penghubung adalah buku yang digunakan untuk menghubungkan kegiatan antara guru (dalam hal ini tim pelaksana) dengan orangtua/wali siswa. Adapun bentuk buku penghubung yang digunakan dalam penelitian ini adalah sebagai berikut: 


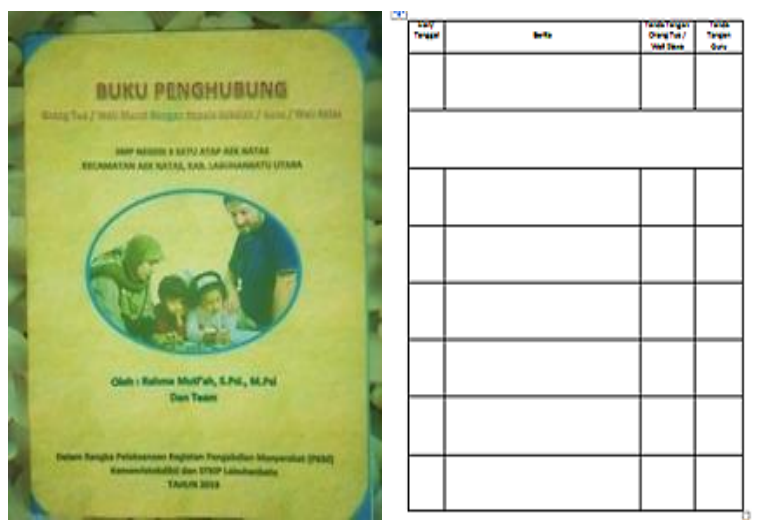

Gambar 6. Buku penghubung

8. Token "Star"

Token "star" adalah sebuah gambar yang di print di kertas BC dan diberi double tip pada belakang kertas untuk di lekatkan di kolom yang telah disediakan ketika siswa mampu menjawab dengan benar dan berhak mendapatkan token. Adapun gambar token "star" adalah seperti yang dibawah ini:

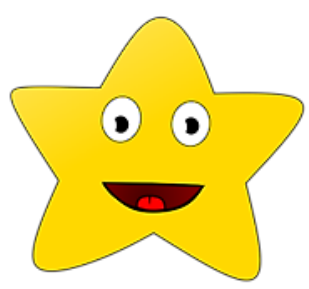

Gambar 7. Token "Star"

\section{ATK, Spidol, dan Infocus}

Alat-alat ini digunakan tim pelaksana selama kegiatan pembelajaran berlangsung. Untuk menuliskan contoh soal maupun untuk menampilkan materi-materi pembelajaran.

Adapun metode pelaksanaan kegiatan pengabdian yang dilakukan adalah sebagai berikut:

1. Identifikasi tingkat kemampuan literasi matematika, minat membaca, dan dukungan sosial

Pada tahap ini siswa diberikan angket minat membaca matematika, angket dukungan sosial dan tes kemampuan literasi matematika siswa. Hal ini dilakukan untuk melihat kemampuan awal sebelum dilaksanakan pengabdian dan sebagai pembanding dengan tes akhir sebagai indikator keberhasilan kegiatan pengabdian.

2. Identifikasi jumlah literatur buku matematika yang ada di perpustakaan sekolah dan menseleksi buku/referensi matematika yang akan disumbangkan

Pada tahap ini tim pelaksana melakukan identifikasi jumlah buku yang dimiliki perpustakaan dan melakukan pencarian dan membeli bukubuku/literatur matematika yang akan disumbangkan ke perpustakaan. Buku-buku ini juga yang akan digunakan siswa untuk kegiatan literasi sebelum pembelajaran dimulai.

3. Menyiapkan buku yaitu "buku latihan soal”, "buku self control", "buku penghubung" dan menyiapkan bahan-bahan yang dibutuhkan dalam pembelajaran PMR

Pada tahap ini tim pelaksana membuat "buku latihan soal", "buku self control”, "buku penghubung" dan "buku token". Setelah buku-buku ini selesai disusun maka kemudian yang dilakukan adalah menyiapkan kebutuhan pembelajaran PMR yaitu media-media yang dibutuhkan seperti kertas warna, spidol, token "star" dan lain-lain.

4. Melakukan kegiatan psikoedukasi dengan siswa, guru dan orangtua

Pada tahap ini tim pelaksana melakukan psikoedukasi kepada siswa terlebih dahulu untuk memahamkan siswa tentang kemampuan literasi matematika, minat membaca matematika dan dukungan sosial keluarga. Selain itu pelaksanaan psikoedukasi ini juga menjelaskankan tentang fungsi-fungsi buku yang akan digunakan ketika pelaksanaan pengabdian. Pada saat ini juga dibahas tentang hadiah dan aturan-aturan pada pelaksanaan token ekonomi yang terdapat pada buku token. Hal 
ini dilakukan agar token dan hadiah yang diberikan sesuai dengan keinginan siswa. Dikhawatirkan jika tidak didiskusikan dengan siswa tentang sistem penukaran token akan membuat siswa tidak tertarik untuk melakukan kegiatan membaca dan mengerjakan soal karena merasa hadiah yang ditawarkan tidak menarik.

Sedangkan psikoedukasi kepada guru dan orangtua dilakukan untuk menjelaskan kepada guru dan orangtua mengenai kegiatan pengabdian dan sistem pelaksanaannya. Selain itu menjelaskan tentang kemampuan literasi matematika, minat membaca, modifikasi perilaku dan teknik token ekonomi. Diharapkan agar orangtua dan guru paham dengan kegiatan apa yang akan mereka lakukan untuk membantu kegiatan pengabdian ini.

5. Melakukan kegiatan pembelajaran PMR dan teknik token ekonomi.

Pada tahap ini dilakukan dengan cara:

a. 10 menit diawal adalah pengumuman jumlah token (bintang) yang diperoleh siswa

b. 15 menit siswa diminta untuk membaca materi dari modul dan berbagai sumber

c. 15 menit mengerjakan tugas soal pada buku latihan soal, dimana jumlah soal yang dikerjakan sesuai dengan indikator capaian pada hari tersebut

d. 1 jam 15 menit adalah pelaksanaan pembelajaran dengan PMR, yang terdiri dari:

1) Kegiatan awal; yaitu guru membagi siswa ke dalam kelompok. Untuk pertemuan selanjutnya mentor hanya tinggal mengingatkan peserta untuk duduk berdasarkan kelompok masing-masing

2) Kegiatan inti; mentor memberikan satu soal dengan memanfaatkan kondisi lingkungan yang ada di sekitar siswa. Soal yang diberikan disesuaikan dengan materi yang akan disampaikan. Siswa diminta untuk mengerjakan soal secara berkelompok baik di dalam ruangan maupun di luar ruangan. Selama kegiatan kelompok mentor selalu mendampingi siswa. Setelah selesai diskusi siswa diminta untuk mempresentasikan hasil diskusi dan dilakukan kegiatan interaksi, misal dengan memperdebatkan apakah jawaban yang diberikan satu kelompok sama atau berbeda dengan kelompok lain, kemudian siswa diminta untuk memberikan argumentasi.

3) Diakhir kegiatan atau kegiatan penutup; mentor memberikan penjelasan tambahan tentang konsep-konsep yang sudah dipahami siswa, serta memberikan penjelasan keterkaitan konsep yang dipelajari hari ini dengan konsep-konsep matematika yang lain.

e. 5 menit terakhir, pengumuman tentang tugas yang akan dikerjakan siswa di rumah yang terdapat pada buku "self control"

6. Melaksanakan tes akhir untuk melihat kemampuan literasi matematika siswa, minat membaca dan dukungan sosial setelah dilaksanakan kegiatan pengabdian. Pada tahap ini kembali dilakukan pembagian angket minat membaca, angket dukungan sosial dan tes kemampuan literasi matematika. Hasil akhir ini akan dibandingkan dengan hasil tes awal untuk melihat keberhasilan kegiatan pelaksanaan pengabdian,

7. Melaksanakan kegiatan seminar sebagai bahan evaluasi pelaksanaan modifikasi perilaku dan pembelajaran PMR sekaligus laporan hasil pelaksanaan pengabdian. 
Pada tahap ini guru dan orangtua dikumpulkan kembali untuk melakukan evaluasi kegiatan pengabdian dan sekaligus menyampaikan hasil laporan akhir dari kegiatan pengabdian.

8. Evaluasi dan monitoring keberlanjutan kegiatan

Evaluasi dan monitoring keberlanjutan kegiatan dilakukan dengan melakukan wawancara dengan beberapa siswa, guru matematika, kepala sekolah dan beberapa orang tua siswa.

\section{HASIL DAN PEMBAHASAN}

Hasil dari pelaksanaan pengabdian ini, akan dijabarkan dibawah ini sesuai dengan langkah-langkah atau metode pelaksanaan kegiatan pengabdian yang dilakukan.

1. Identifikasi tingkat kemampuan literasi matematika, minat membaca dan dukungan sosial keluarga

Pada pelaksanaan identifikasi tingkat kemampuan literasi matematika, minat membaca dan dukungan sosial keluarga di lakukan dengan memberikan buku pretes kepada siswa. Hasil dari pelaksanaan identifikasi diperoleh dibawah ini:

a. Hasil identifikasi literasi matematika siswa

Pada saat pretes diperoleh nilai rata-rata kemampuan literasi matematika siswa adalah 12.44 dan standar deviasi 13.53.

Tabel I. Literasi matematika siswa pretes

\begin{tabular}{clcc}
\hline No & Skor Rata-Rata & Kategori & Jumlah \\
\hline 1 & $X \geq 26$ & Tinggi & 5 \\
2 & $1 \leq X<26$ & Sedang & 17 \\
3 & $X<1$ & Rendah & 8 \\
\hline \multicolumn{3}{r}{ Total } & 30 \\
\hline
\end{tabular}

b. Hasil identifikasi minat membaca siswa

Pada saat pretes diperoleh nilai rata-rata minat membaca matematika siswa adalah 53.47 dan standar deviasi 14.85 .
Tabel II. Minat membaca siswa pretes

\begin{tabular}{cllc}
\hline No & \multicolumn{1}{c}{ Skor Rata-Rata } & Kategori & Jumlah \\
\hline 1 & $X \geq 68$ & Tinggi & 3 \\
2 & $38 \leq X<68$ & Sedang & 21 \\
3 & $X<38$ & Rendah & 6 \\
\hline \multicolumn{2}{r}{ Total } & 30 \\
\hline \multicolumn{2}{r}{}
\end{tabular}

c. Hasil identifikasi dukungan sosial keluarga siswa Pada saat pretes diperoleh nilai rata-rata dukungan sosial keluarga siswa adalah 63.63 dan standar deviasi 10.85 .

Tabel III. Dukungan sosial keluarga pretes

\begin{tabular}{cllc}
\hline No & \multicolumn{1}{c}{ Skor Rata-Rata } & Kategori & Jumlah \\
\hline 1 & $X \geq 75$ & Tinggi & 3 \\
2 & $53 \leq X<75$ & Sedang & 22 \\
3 & $X<53$ & Rendah & 5 \\
\hline \multicolumn{2}{r}{ Total } & 30 \\
\hline \multicolumn{2}{r}{} \\
\hline
\end{tabular}

2. Identifikasi jumlah literatur buku matematika yang ada di perpustakaan sekolah dan menseleksi buku/referensi matematika yang akan disumbangkan

Berdasarkan dari hasil identifikasi jumlah literatur buku matematika yang ada diperpustakaan diperoleh bahwa umumnya buku matematika yang ada di sekolah adalah buku-buku pegangan atau buku materi pembelajaran matematika. Untuk bukubuku matematika yang berkaitan dengan peningkatan kompetensi matematika misal buku yang bertema tentang soal-soal OSN, rumus matematika, kiat belajar cepat matematika dan lainlain tidak terdapat didalam perpustakaan. Sehingga buku yang disumbangkan untuk sekolah adalah buku-buku tentang matematika namun bukan buku wajib materi pelajaran di sekolah.

3. Menyiapkan buku yaitu "buku latihan soal”, "buku self control", "buku penghubung" dan menyiapkan bahan-bahan yang dibutuhkan dalam pembelajaran PMR

Menyiapkan buku yaitu yaitu "buku latihan soal", "buku self control", "buku penghubung" dan menyiapkan bahan-bahan yang dibutuhkan dalam pembelajaran PMR. Seluruh buku ini dijadikan 
alat/bahan untuk pelaksanaan kegiatan. Seluruh alat/bahan disiapkan tim pelaksana sebelum kegiatan pelaksanaan pembelajaran dilakukan. Seluruh alat/bahan dalam bentuk jilidan, dan dapat dibawa pulang oleh siswa dan pada akhir kegiatan seluruh buku diserahkan kembali kepada siswa untuk dapat dimiliki. Harapannya buku-buku ini menjadi alat/bahan untuk memperdalam materi dan meningkatkan kemampuan literasi matematika siswa.

4. Melakukan kegiatan psikoedukasi dengan siswa, guru dan orangtua

Kegiatan psikoedukasi dilaksanakan dua kali, yang pertama pada siswa dan yang kedua pada guru dan orangtua. Kegiatan psikoedukasi ke siswa berupa pemberian pemahaman mengenai fungsi dan tujuan dari pelaksanaan kegiatan, literasi matematika, minat membaca, token ekonomi dan dukungan sosial keluarga, menggunakan dan manfaat dari seluruh bahan/alat pelaksanaan pengabdian.

Kegiatan psikoedukasi ke orangtua memberikan materi dengan harapan orangtua dna guru paham tentang tatacara pelaksanaan pengabdian, peran guru dan orangtua selama pelaksanaan pengabdian, menjelaskan tentang fungsi guru dan orangtua dalam meningkatkan kemampuan literasi matematika dan meningkatkan hasil belajar siswa melalui kegiatan buku pendukung. Selain itu kepada orangtua juga dijelaskan tentang fungsi, manfaat dan sistem pelaksanaan token ekonomi dan penerapannya pada kehidupan sehari-hari ketika akan membentuk atau menghilangkan perilaku anak. Dari hasil kegiatan pelaksanaan psikoedukasi terihat orangtua terlihat lebih antusias mengenai peran mereka dalam kegiatan belajar anak dan membantu anak untuk meraih prestasi dengan kondisi perekonomian keluarga mereka yang cenderung menengah kebawah. Selain itu orangtua juga banyak yang bertanya tentang bagaimana cara agar dapat membentuk perilaku anak dengan menggunakan prinsip token ekonomi namun dengan menggunakan biaya yang relatif terjangkau (Novrinda et al., 2017).

5. Melakukan kegiatan pembelajaran PMR dan teknik token ekonomi

Pelaksanaan kegiatan pembelajaran dilakukan selama lebih kurang 3 minggu, dilakukan pada hari senin s/d sabtu dari pukul 10.00 s/d 12.30 wib, dimana kegiatan pembelajaran dilakukan dengan pendekatan matematika realistik dengan berbantuan metode resitasi dan metode token ekonomi. Pelaksanaan kegiatan dilakukan selama 18 pertemuan, sebelum pemberian perlakukan terlebih dahulu dilakukan pretes, psikoedukasi ke siswa, guru dan orangtua setelah dilakukan perlakukan kemudian dilaksanakan postes, kemudian sosialisasi hasil pelaksanaan kegiatan ke guru dan orangtua serta pembagian hadiah token sekaligus perpisahan dengan siswa. Kegiatan pelaksanaan diawali dengan memberikan materi pembelajaran dengan menggunakan pendekatan matematika realistik. Pada saat pembelajaran diberikan disesuaikan dengan indikator dari literasi matematika yaitu mathematical thinking and reasoning, mathematical argumentation, mathematical communication, modelling, problem solving, representation, symbol, dan tools (Fathani, 2016).

Pelaksanaan pembelajaran dengan PMR pertama kali mentor memberikan materi sesuai dengan indikator yang hendak dicapai, kemudian dilanjutkan dengan mengajak siswa untuk mengerjakan soal yang disusun mentor berdasarkan kondisi yang ada di lingkungan sekolah, misalkan pada materi barisan dan deret siswa diminta untuk 
mencari penyelesaian soal tentang menghitung jumlah asbes yang dibutuhkan seorang tukang berdasarkan jumlah kelas yang hendak dibangun. Setelah selesai mengerjakan soal siswa diminta untuk memberikan argumentasi dari hasil penyelesaian soal yang telah diberikan. Selama pelaksanaan pembahasan soal siswa diajak untuk berdiskusi, untuk memberikan penilaian apakah argumentasi yang diberikan teman mereka benar atau salah. Diakhir pelaksanaan PMR mentor memberikan materi tambahan untuk membenarkan argumentasi atau indikator yang lain sesuai dengan tujuan pembelajaran.

Pada kegiatan pembelajaran peneliti juga menerapkan metode resitasi yaitu pemberian tugas, dimana siswa untuk mengerjakan tugas-tugas yang disusun oleh peneliti, kemudian siswa yang mampu menyelesaikan tugas akan mendapatkan "bintang" (token ekonomi) yang akan dikoleksi siswa dengan menempelkan "bintang " di lembar kerja. Diakhir pembelajaran setelah $18 x$ pertemuan, seluruh token "bintang" yang dikoleksi siswa akan ditukarkan dengan hadiah-hadiah yang telah disusun oleh peneliti dan siswa sebelum kegiatan pembelajaran dimulai. Hadiah-hadiah token yang diberikan adalah alat-alat sekolah atau kebutuhan siswa yang tidak melebihi dari Rp. 50.000 dan siswa yang mampu mengumpulkan hingga 100 bintang akan mendapatkan kesempatan untuk berkunjung ke kota "Medan" (Ibu Kota Propinsi) dan siswa pada umumnya tidak pernah datang berkunjung ke Kota "Medan".

Berikut adalah foto-foto kegiatan pelaksanaan pembelajaran dengan PMR, berbantuan metode resitasi dan token ekonomi.

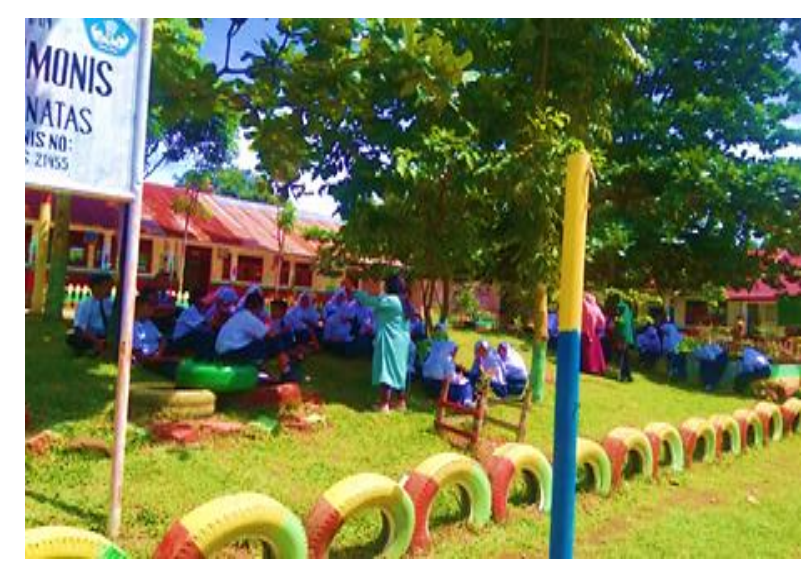

Gambar 8. Pelaksanaan kegiatan pembelajaran untuk menjelaskan konsep barisan dan deret dengan menggunakan pagar sekolah

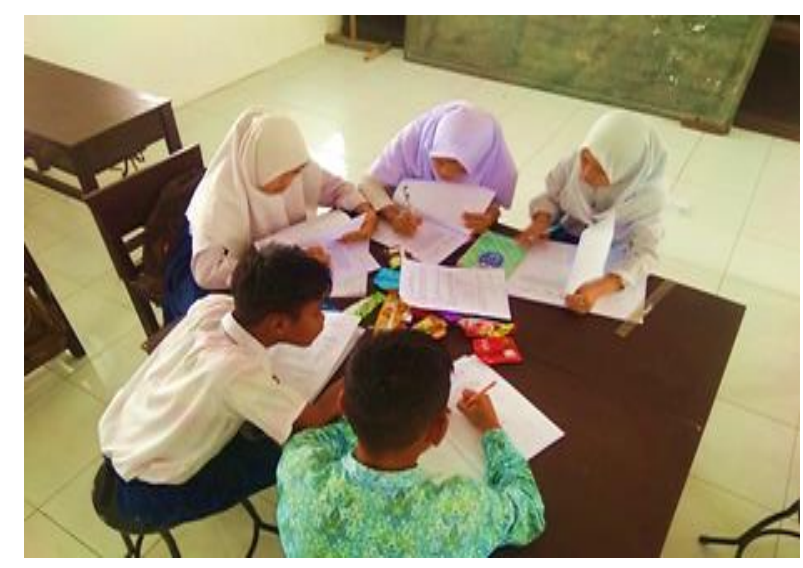

Gambar 9. Pelaksanaan kegiatan pembelajaran unutk menjelaskan tentang teori bilangan dengan menggunakan penghitungan jumlah kalori di beberapa snack yang selalu dikonsumsi siswa

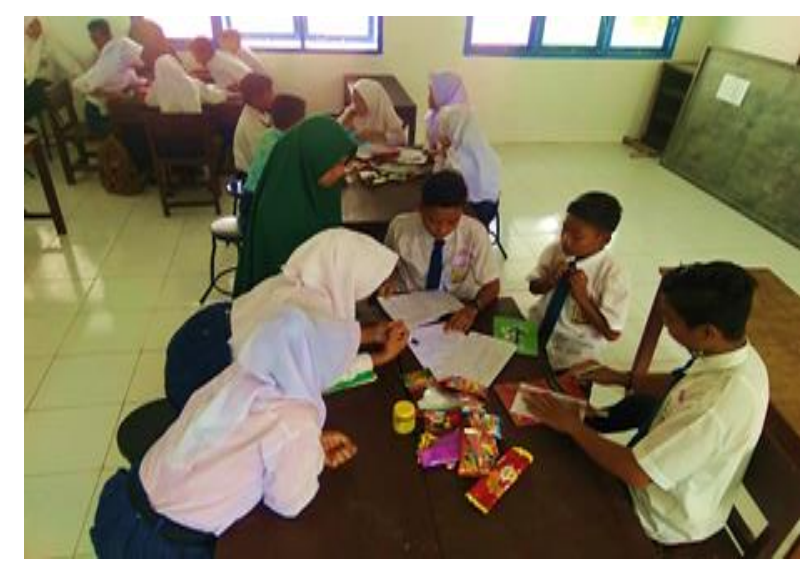

Gambar 10. Pendampingan dari mentor ketika siswa mengerjakan tugas konteks. Mentor membantu mengarahkan dengan memberikan pertanyaan stimulus agar siswa mampu menjawab soal pada tugas yang diberikan 


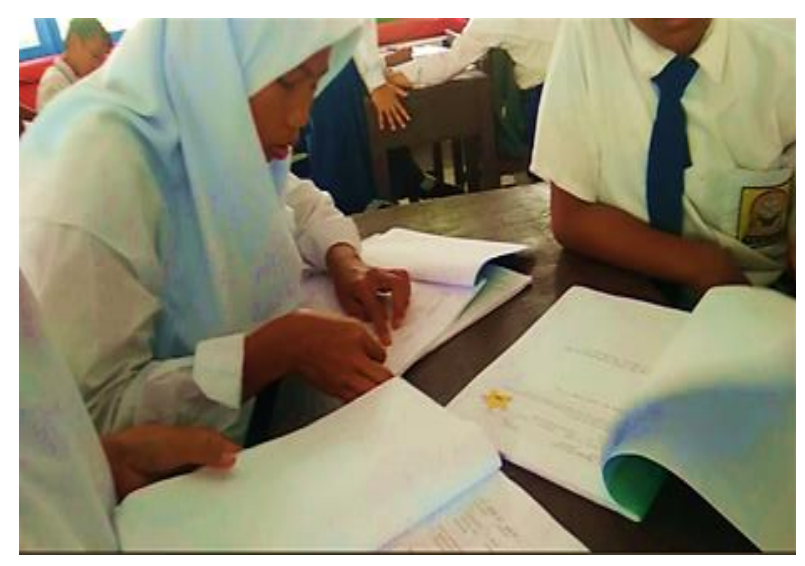

Gambar 11. Siswa menempelkan token di buku tugas ketika berhasil menyelesaikan tugas yang diberikan

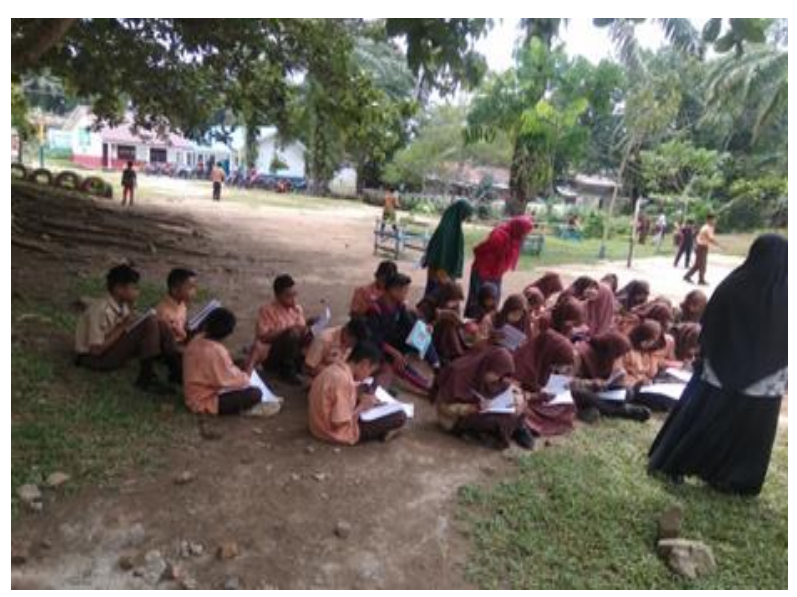

Gambar 12. Pelaksanaan kegiatan pembelajaran untuk menjelaskan konsep bangun ruang dengan menggunakan bangunan di sekolah

6. Melakukan tes akhir untuk melihat kemampuan literasi matematika siswa, minat membaca dan dukungan sosial setelah dilaksanakan kegiatan pengabdian

Dari hasil pelaksanaan tes akhir diperoleh hasil sebagai berikut:

a. Hasil akhir literasi matematika siswa

Pada saat postes diperoleh nilai rata-rata kemampuan literasi matematika siswa adalah 57,99 dan standar deviasi 20,5.

Tabel IV. Literasi matematika postes

\begin{tabular}{cllc}
\hline No & \multicolumn{1}{c}{ Skor Rata-Rata } & Kategori & Jumlah \\
\hline 1 & $X \geq 69$ & Tinggi & 11 \\
2 & $35 \leq X<69$ & Sedang & 13 \\
3 & $X<35$ & Rendah & 6 \\
\hline \multicolumn{2}{r}{ Total } & 30 \\
\hline
\end{tabular}

b. Hasil identifikasi minat membaca siswa

Pada saat postes diperoleh nilai rata-rata minat membaca matematika siswa adalah 70,77 dan standar deviasi 14,73.

Tabel V. Minat membaca matematika postes

\begin{tabular}{cllc}
\hline No & \multicolumn{1}{c}{ Skor Rata-Rata } & Kategori & Jumlah \\
\hline 1 & $X \geq 86$ & Tinggi & 12 \\
2 & $56 \leq X<86$ & Sedang & 14 \\
3 & $X<56$ & Rendah & 4 \\
\hline \multicolumn{3}{r}{ Total } & 30 \\
\hline
\end{tabular}

c. Hasil identifikasi dukungan sosial keluarga siswa Pada saat postes diperoleh nilai rata-rata dukungan sosial keluarga siswa adalah 70,23 dan standar deviasi 16,56.

Tabel VI. Dukungan sosial keluarga postes

\begin{tabular}{cllc}
\hline No & \multicolumn{1}{c}{ Skor Rata-Rata } & Kategori & Jumlah \\
\hline 1 & $X \geq 87$ & Tinggi & 7 \\
2 & $53 \leq X<87$ & Sedang & 19 \\
3 & $X<53$ & Rendah & 4 \\
\hline \multicolumn{2}{r}{ Total } & 30 \\
\hline
\end{tabular}

Tabel VII. Perbandingan jumlah siswa pada setiap kategori Pretes dan Postes

\begin{tabular}{|c|c|c|c|c|}
\hline Variabel & Kategori & Pretes & Postes & Keterangan \\
\hline \multirow{3}{*}{$\begin{array}{l}\text { Kemampuan } \\
\text { Literasi } \\
\text { Matematika }\end{array}$} & Tinggi & 5 & 11 & \multirow{3}{*}{$\begin{array}{l}\text { Rerata } \\
\text { pretes } 12,44 \\
\text { dan rerata } \\
\text { postes } \\
57,99\end{array}$} \\
\hline & Sedang & 17 & 13 & \\
\hline & Rendah & 8 & 6 & \\
\hline \multirow{3}{*}{$\begin{array}{l}\text { Minat } \\
\text { membaca }\end{array}$} & Tinggi & 3 & 12 & \multirow{3}{*}{$\begin{array}{l}\text { Rerata } \\
\text { pretes } 53,47 \\
\text { dan rerata } \\
\text { postes } \\
70,77\end{array}$} \\
\hline & Sedang & 21 & 14 & \\
\hline & Rendah & 6 & 4 & \\
\hline \multirow{3}{*}{$\begin{array}{l}\text { Dukungan } \\
\text { Sosial } \\
\text { Keluarga }\end{array}$} & Tinggi & 3 & 7 & \multirow{3}{*}{$\begin{array}{l}\text { Rerata } \\
\text { pretes } 63,3 \\
\text { dan rerata } \\
\text { postes } \\
70,23\end{array}$} \\
\hline & Sedang & 22 & 19 & \\
\hline & Rendah & 5 & 4 & \\
\hline
\end{tabular}

Berdasarkan hasil dari perbandingan antara jumlah siswa yang berada dalam kategori tinggi pada kemampuan literasi matematika, minat membaca matematika dan dukungan sosial keluarga mengalami peningkatan antara pretest dan postes. Sedangkan untuk kategori sedang dan kategori rendah pada kemampuan literasi matematika, minat membaca matematika dan dukungan sosial keluarga mengalami penurunan dari hasil pretes dan postes. Sehingga dapat disimpulkan pelaksanaan 
pengabdian berhasil dilakukan karena mampu meningkatkan nilai rerata dan jumlah siswa pada kategori tinggi sebelum dan sesudah pelaksanaan pengabdian. Ini sebagai bukti bahwa tolak ukur keberhasilan pelaksanaan pengabdian mampu meningkatkan pengetahuan dan pemahaman mitra berhasil dicapai.

7. Melaksanakan kegiatan seminar sebagai bahan evaluasi pelaksanaan modifikasi perilaku dan pembelajaran PMR sekaligus laporan hasil pelaksanaan pengabdian

Pelaksanaan kegiatan seminar dilakukan dengan menyampaikan hasil pelaksanaan pengabdian kepada orangtua dan guru. Kemudian diadakan tanya jawab dengan guru dan orangtua mengenai perkembangan kebiasaan belajar dan hasil belajar siswa setelah kegiatan pelaksanaan pengabdian dilakukan. Menurut pendapat orangtua siswa mengalami perubahan kebiasaan belajar, siswa yang pada awalnya tidak mau dan harus dipaksa untuk belajar di rumah dan mengulang kembali pelajaran, setelah kegiatan pelaksanaan siswa sudah mau untuk belajar sendiri dirumah tanpa disuruh ataupun dipaksa. Namun ada beberapa orangtua yang masih juga mengeluh dengan kebiasaan anak yang tidak mau belajar jika tidak ada tugas yang diberikan guru. Pada saat pelaksanaan pengabdian tiap malam siswa mengerjakan tugas karena memang ada tugas dari mentor, namun saat ini karena terkadang ada guru yang tidak memberikan tugas di rumah siswa tidak mau mengulang materi di rumah. Untuk hasil belajar menurut guru, para peserta pelaksana pengabdian terlihat meningkat, dan guru juga telah menerapkan kegiatan pembelajaran dengan PMR untuk beberapa materi dan pertemuan.
8. Evaluasi monitoring keberlanjutan kegiatan

Dari hasil evaluasi monitoring keberlanjutan kegiatan, dilakukan wawancara dengan kepala sekolah, guru matematika, siswa dan salah satu orangtua siswa. Dari kepala sekolah disebutkan menjadikan program literasi matematika menjadi salah satu agenda dan dijadikan salah satu indikator pembelajaran matematika di sekolah dengan mengajak guru matematika untuk menjalankan program tersebut. Selain itu meminta guru Bahasa Indonesia untuk lebih meningkatkan kemampuan membaca pemahaman siswa agar siswa mampu memahami soal-soal cerita pada soal-soal PISA.

Berdasarkan hasil dari pelaksanaan pengabdian diatas, yang perlu menjadi bahan untuk didiskusikan adalah tentang peningkatan literasi matematika yang masih dalam rerata cukup memuaskan yaitu 57,99 dari rerata awal 12,44 sehingga selisih rerata kemampuan literasi matematika siswa setelah mendapatkan pembelajaran dengan pendekatan PMR berbantuan metode resitasi, token ekonomi dan dukungan keluarga adalah 45,55. secara keseluruhan, jika dilihat dari selisih skor nilai literasi terbukti bahwa ada peningkatan kemampuan literasi matematika siswa sebelum dan sesudah. Ini sesuai berdasarkan hasil peneitian yang dilakukan oleh Larasaty et al. (2018) pembelajaran dengan PMRI lebih baik daripada pembelajaran konvensional dalam meningkatkan kemampuan literasi matematika terlihat dari selisih literasi matematika awal-akhir pembelajaran. Hanya saja jika dilihat dari rerata dari postes yaitu 57,99, pelaksanaan pengabdian yang dilakukan masih kurang memuaskan, namun jika ditinjau dari faktor yang mempengaruhi, sangat wajar jika peningkatan yang terjadi signifikan namun dengan selisih yang kecil. Selain karena minat membaca dan dukungan sosial keluarga, ada beberapa faktor yang juga mempengaruhi kemampuan literasi matematika siswa, menurut 
Khoirudin et al. (2017) bahwa kemampuan literasi matematika siswa dipengaruhi beberapa faktor antara lain materi yang dipilih, pembelajaran yang diberikan oleh guru, lingkungan kelas, dukungan lingkungan keluarga, kesiapakan dalam pelaksanaan tes, dan kemampuan yang dimiliki setiap siswa sendiri.

Berdasarkan hasil observasi yang dilakukan tim pelaksana pengabdian, umumnya kesulitan siswa dipengaruhi oleh kemampuan siswa dalam membaca, masih terlihat ada siswa yang memiliki kemampuan membaca masih rendah, siswa hanya mampu membaca dan belum termasuk kategori lancar membaca. Hal ini juga mempengaruhi kemampuan siswa memahami soal PISA karena umumnya soal literasi PISA adalah soalsoal dalam bentuk cerita. Jika siswa memiliki kemampuan membaca rendah maka kemampuan dirinya dalam memahami soal cerita juga akan rendah sehingga siswa akan kesulitan untuk mengerjakan soal dalam bentuk cerita. Kemampuan menyelesaikan soal cerita juga dipengaruhi kemampuan membaca pemahaman siswa sesuai dengan hasil penelitian yang dilakukan oleh Praditha et al. (2017) bahwa ada hubungan yang berarti atau signifikan antara kemamuan membaca pemahaman dengan kemampuan menyelesaikan soal cerita matematika siswa.

Selain itu faktor lain menurut tim pelaksana pengabdian yang mempengaruhi peningkatan literasi matematika siswa adalah jenis kelamin, anggota atau peserta pengabdian umumnya adalah perempuan, dimana jumlah siswa berjenis kelamin perempuan adalah 22 orang dan laki-laki berjumlah 8 orang. Padahal kemampuan literasi matematika siswa laki-laki lebih baik dari siswa perempuan. Dengan perbandingan jumlah laki-laki dan perempuan yang tinggi memungkinkan hal ini mempengaruhi hasil akhir literasi matematika siswa setelah kegiatan pembelajaran. Berdasarkan penelitian yang dilakukan Lastuti et al.
(2018) didapatkan hasil ada beberapa siswa yang dapat mengerjakan beberapa soal dengan tingkat level yang berbeda dan lebih banyak siswa laki-laki yang dapat mengerjakan soal literasi matematika yang berdasarkan PISA.

\section{KESIMPULAN}

Berdasarkan dari penjabaran tujuan dari pelaksanaan pengabdian dan hasil pelaksanaan yang diperoleh maka dapat disimpulkan bahwa salah satu upaya yang dapat dilakukan untuk meningkatkan kemampuan literasi matematika adalah dengan menggunakan pendekatan PMR berbantuan metode resitasi, token ekonomi dan buku penghubung. Berdasarkan hal tersebut, hendaknya pelaksanaan pengabdian selanjutnya dalam upaya meningkatkan literasi matematika siswa, selain mempertimbangkan faktor minat membaca dan dukungan sosial keluarga, tim pelaksana pengabdian maupun penelitian hendaknya mempertimbangkan sampel yang dijadikan peserta pengabdian ditinjau dan dipilih berdasarkan kemampuan membaca siswa, dan jumlah perbandingan siswa berdasarkan jenis kelamin.

\section{UCAPAN TERIMA KASIH}

Ucapan terima kasih serta penghargaan sebesarbesarnya tim pelaksana pengabdian yang berjudul "Upaya Meningkatkan Kemampuan Literasi Matematika di SMP Negeri 3 Satu Atap Aek Natas" kepada DRPM Kemenristekdikdi selaku pemberi dana/penyedia anggaran pada Skema Program Kemitraan Masyarakat tahun pelaksanaan 2019, Ketua STKIP Labuhan Batu yang saat ini sudah menjadi Dekan FKIP Universitas Labuhanbatu sebagai lembaga tempat tim pelaksana mengabdi, LPPM STKIP Labuhanbatu, Kepala Sekolah, Guru dan Tenaga Kependidikan serta seluruh siswa-siswa SMP Negeri 3 Satu Atap Aek Natas terutama 30 siswa yang menjadi peserta selama kegiatan 
pelaksanaan berlangsung, serta seluruh tim pelaksana pengabdian yang telah banyak membantu untuk mensukseskan kegiatan pengabdian ini.

\section{REFERENSI}

Arisma, O.A. 2012. Peningkatan Minat Dan Kemampuan Membaca Melalui Penerapan Program Jam Baca Sekolah Di Kelas VII SMP Negeri 1 Puri. Skripsi. Malang: Universitas Negeri Malang.

Cahyani, I.R. 2016. Peran orang tua dan guru dalam mengembangkan literasi dini (early literacy) di kabupaten sidoarjo. Skripsi. Surabaya: Universitas Airlangga.

Fathani, A.H. 2016. Pengembangan Literasi Matematika Sekolah Dalam Perspektif Multiple Intelligences. Edu Sains: Jurnal Pendidikan Sains dan Matematika. 4(2):136-150. https://doi.org/10.23971/eds.v4i2.524

Kaisar, M.I. 2017. Pengaruh Persepsi Minat Baca Matematika Terhadap Kemampuan Literasi Matematika Pada Materi Fungsi Komposisi dan Fungsi Invers Pada Siswa Kelas XI di Makassar. Skripsi. Makssar: Universitas Negeri Makassar.

Kharizmi, M. 2015. Kesulitan Siswa Sekolah Dasar Dalam Meningkatkan Kemampuan Literasi. JUPENDAS (Jurnal Pendidikan Dasar). 2(2):1121.

Khoirudin, A., Styawati, R.D., Nursyahida, F. 2017. Profil Kemampuan Literasi Matematika Siswa Berkemampuan Matematis Rendah Dalam Menyelesaikan Soal Berbentuk PISA. AKSIOMA: Jurnal Matematika dan Pendidikan Matematika. $\quad$ 8(2):33-42. http://dx.doi.org/10.26877/aks.v8i2.1839

Larasaty, B.M., Mustiani, M., Pratini, H.S. 2018. Peningkatan Kemampuan Literasi Matematika Siswa Kelas VIII SMP BOPKRI 3 Yogyakarta Melalui Pendekatan Pmri Berbasis PISA Pada Materi Pokok SPLDV. In Prosiding Seminar Nasional Pendidikan Matematika Etnomatnesia. Yogyakarta: Universitas Sarjanawiyata Tamansiswa.

Lastuti, F.A.O., Maharani, R.M., Pratini, H.S. 2018. Analisis Kemampuan Literasi Matematika
Kelas VIII Menurut Gender. In Prosiding Seminar Nasional Pendidikan Matematika Etnomatnesia. Yogyakarta: Universitas Sarjanawiyata Tamansiswa.

Madyaratria, D.Y., Wardono, W., Prasetyo, A.P.B. 2019. Kemampuan Literasi Matematika Siswa pada Pembelajaran Problem Based Learning dengan Tinjauan Gaya Belajar. PRISMA, Prosiding Seminar Nasional Matematika. 2:648658.

Mahdiansyah, Rahmawati. 2014. Literasi Matematika Siswa Pendidikan Menengah: Analisis Menggunakan Desain Tes Internasional dengan Konteks Indonesia. Jurnal Pendidikan dan Kebudayaan. 20(4):452-469. http://dx.doi.org/10.24832/jpnk.v20i4.158

Masjaya, Wardono. 2018. Pentingnya Kemampuan Literasi Matematika untuk Menumbuhkan Kemampuan Koneksi Matematika dalam Meningkatkan SDM. PRISMA, Prosiding Seminar Nasional Matematika. 1:568-574.

Muti'ah, R. 2017. Hubungan Antara Minat Belajar, Fasilitas Belajar Dan Keterlibatan Orang Tua Dengan Prestasi Belajar. Jurnal Pembelajaran dan Matematika Sigma (JPMS). 3(1):48-58. https://doi.org/10.36987/jpms.v3i1.1281

Novrinda, N., Kurniah, N., Yulidesni, Y. 2017. Peran Orangtua Dalam Pendidikan Anak Usia Dini Ditinjau Dari Latar Belakang Pendidikan. Jurnal Ilmiah Potensia. 2(1):39-46. https://doi.org/10.33369/jip.2.1.39-46

Praditha, I.M.A., Kusmariyatni, N., Japa, I.G.N. 2017. Hubungan Antara Kemampuan Membaca Pemahaman Dengan Menyelesaikan Soal Cerita Matematika Siswa Kelas IV. Mimbar PGSD Undiksha. 5(2):1-10. http://dx.doi.org/10.23887/jjpgsd.v5i2.10987

Rahmani, M.A.C., Haryono, H., Purwanti, E. 2017. Pengembangan Media Komunikasi Buku Penghubung Berbasis SMS Gateway dan Mobile Web. Innovative Journal of Curriculum and Educational Technology. 6(2):15-21.

Siswowijoyo, M., Tiya, K. 2014. Deskripsi Kemampuan Literasi Matematika Siswa Kelas IX SMP Negeri Di Kota Raha. Jurnal Penelitian Pendidikan Matematika. 2(2):73-90. http://dx.doi.org/10.36709/jppm.v2i2.3095 